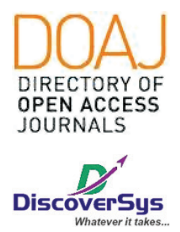

Published by DiscoverSys

\section{Hemiartroplasti Bipolar menghasilkan luaran C-Reactive Protein dan Harris Hip Score yang lebih tinggi dibandingkan Cephalomedulary Nailing}

\author{
Komang Septian Sandiwidayat, ${ }^{1 *}$ Putu Astawa, ${ }^{2}$ Ketut Gede Mulyadi Ridia, ${ }^{2}$ \\ Ketut Siki Kawiyana, ${ }^{2}$ I Wayan Suryanto Dusak, ${ }^{2}$ I Ketut Suyasa, ${ }^{2}$ \\ I Gede Eka Wiratnaya, ${ }^{2}$ Anak Agung Wiradewi Lestari ${ }^{3}$
}

\section{ABSTRACT}

Background: Bipolar Hemiarthroplasty and Cephalomedullary Nailing (PFNA) are operative procedures for the management of proximal femoral fractures. Both of these surgical techniques have their respective advantages and disadvantages. This study aims to determine the differences in biological and functional outcomes. C-Reactive Protein (CRP) used to measure inflammation due to tissue damage and Harris Hip Score (HHS) used to measure functional output. This study hoped to facilitate the selection of appropriate techniques for the treatment of proximal femoral fractures.

Methods: Prospective cohort study conducted among patient with proximal femoral fractures who underwent Bipolar Hemiarthroplasty and PFNA surgery. CRP levels were examined before surgery and 12 hours postoperatively. The HHS assessment was performed at weeks 4 , 6 , and 8 postoperatively.

Results: In general, the preoperative CRP levels of the groups undergoing Bipolar Hemiarthroplasty and PFNA were not significantly different (32.4 \pm 16.7 and $33.7 \pm 17.1 ; p>0.05)$, whereas postoperatively, Bipolar Hemiarthroplasty shown significantly higher CRP $(76.5 \pm 27.3$ and $42.6 \pm 17.6 ; p<0.0001)$. Similar results were also shown from the $\triangle C R P$ analysis $(45.1 \pm 22.1$ and $8.9 \pm 3.2 ; p<0.0001)$. The mean HHS score was higher in the Bipolar Hemiarthroplasty group than in PFNA group at each measurement. At the 4th week, the mean HHS score did not show a significant difference $(52.3 \pm 4.2$ vs $52.2 \pm 5.4 ; p>0.05)$. The 6th week evaluation showed Bipolar Hemiarthroplasty had a mean HHS of $76.5 \pm 4.6$ while PFNA $61.4 \pm 5.4$ ( $p<0.0001)$. At week 8, HHS in Bipolar Hemiarthroplasty was consistently higher than PFNA $(89.43 \pm 4.5$ and $74.95 \pm 4.9 ; p<0.0001)$. The Bipolar Hemiarthroplasty group was hospitalized $56 \%$ longer $(6.1 \pm 1.3$ and $3.9 \pm 1.3$ days; $p<0.0001)$ and the Bipolar Hemiarthroplasty had an average bleeding volume of 4.5 times more $(407.4 \pm 122.8$ and $90 \pm 13 \mathrm{ml} ; \mathrm{p}<0.0001)$.

Conclusion: Bipolar Hemiarthroplasty and PFNA procedures have significantly different functional and biological outcomes. The postoperative HHS score in Bipolar Hemiarthroplasty is better but with a higher delta CRP.

Keywords: Bipolar Hemiarthroplasty, Cephalomedullary Nailing, Harris Hip Score, C-reactive protein

Cite This Article: Sandiwidayat, K.S., Astawa, P., Ridia, K.G.M. 2020. Hemiartroplasti Bipolar menghasilkan luaran C-Reactive Protein dan Harris Hip Score yang lebih tinggi dibandingkan Cephalomedulary Nailing. Intisari Sains Medis 11(1): 346-351. D0I: 10.15562/ism.v11i1.556

1Program Studi Orthopaedi dan Traumatologi, Fakultas Kedokteran, Universitas Udayana, Bali, Indonesia

2Departemen Orthopaedi dan Traumatologi, Fakultas Kedokteran, Universitas Udayana/ RSUP Sanglah Denpasar, Bali, Indonesia

${ }^{3}$ Departemen Patologi Klinik, Fakultas Kedokteran, Universitas Udayana/RSUP Sanglah Denpasar, Bali, Indonesia

*Korespondensi: Komang Septian Sandiwidayat. Program Studi Orthopaedi dan Traumatologi, Fakultas Kedokteran Universitas Udayana, Bali, Indonesia. septiansandiwidayat@gmail.com

Diterima: 28-26-2019

Disetujui: 11-03-2020

Diterbitkan: 01-04-2020

\title{
ABSTRAK
}

Latar Belakang: Hemiarthroplasti bipolar dan Cephalomedullary Nailing (PFNA) merupakan prosedur operatif penatalaksanaan fraktur proksimal femur. Kedua prosedur tersebut menggunakan pendekatan yang berbeda utamanya pada upaya preservasi bagian proksimal femur. Kedua teknik bedah ini memiliki keuntungan dan kerugian masing-masing. Penelitian ini bertujuan untuk mengetahui perbedaan luaran biologis dan fungsional kedua teknik tersebut. C-Reactive Protein (CRP) digunakan sebagai parameter terkait inflamasi akibat kerusakan jaringan dan Harris Hip Score (HHS) digunakan mengukur luaran fungsional. Studi ini diharapkan dapat mempermudah pemilihan teknik yang tepat untuk penanganan fraktur proksimal femur.

Metode: Penelitian ini adalah penelitian kohort prospektif pada pasien dengan fraktur proksimal femur yang menjalani operasi Hemiartroplasti Bipolar dan PFNA. Kadar CRP diperiksa sebelum operasi dan 12 jam paska operasi. Penilaian HHS dilakukan pada minggu ke-4, 6, dan 8 paska operasi.

Hasil: Secara umum kadar CRP preoperasi kelompok yang menjalani Hemiarthroplasti Bipolar dan PFNA tidak berbeda signifikan $(32,4 \pm 16,7$ dan $33,7 \pm 17,1 ; p>0,05)$, sedangkan pada paska operasi kadar CRP Hemiarthroplasti Bipolar secara signifikan lebih tinggi $(76,5 \pm 27,3$ dan $42,6 \pm 17,6 ; p<0,0001)$. Hasil yang sama juga ditunjukan dari analisis $\Delta C R P(45,1 \pm 22,1$ dan $8,9 \pm 3,2 ; p<0,0001)$. Rerata skor HHS lebih tinggi pada kelompok Hemiarthroplasti Bipolar daripada PFNA pada setiap kali pengukuran. Pada minggu ke-4 nilai rerata HHS tidak menunjukan perbedaan yang signifikan $(52,3 \pm 4,2$ vs $52,2 \pm 5,4$, $p>0,05)$. Evaluasi minggu ke-6 menunjukan Hemiarthroplasti Bipolar memiliki rerata HHS 76,5 $\pm 4,6$ sementara PFNA 61,4 45,4 ( $p<0,0001)$. Pada minggu ke-8, HHS pada Hemiarthroplasti Bipolar konsisten lebih tinggi daripada PFNA $(89,43 \pm 4,5$ dan 74,95 $\pm 4,9 ; p<0,0001)$. Kelompok Hemiarthroplasti Bipolar menjalani rawat inap 56\% lebih lama $(6,1 \pm 1,3$ dan 3,9 $\pm 1,3$ hari; $p<0,0001)$ serta Hemiarthroplasti Bipolar memiliki rerata volume perdarahan 4,5 kali lebih banyak $(407,4 \pm 122,8$ dan $90 \pm 13 \mathrm{ml} ; p<0,0001)$.

Kesimpulan: Prosedur Hemiarthroplasti Bipolar dan PFNA memiliki luaran fungsional dan biologis yang berbeda secara signifikan. Skor HHS pada Hemiarthroplasti Bipolar lebih baik tetapi selisih CRP yang lebih tinggi. 
Kata Kunci: Hemiartroplasti Bipolar, Cephalomedullary Nailing, Harris Hip Score, C-reactive protein

Cite Pasal Ini: Sandiwidayat, K.S., Astawa, P., Ridia, K.G.M. 2020. Hemiartroplasti Bipolar menghasilkan luaran C-Reactive Protein dan Harris Hip Score yang lebih tinggi dibandingkan Cephalomedulary Nailing. Intisari Sains Medis 11(1): 346-351. D0I: 10.15562/ism.v11i1.556

\section{PENDAHULUAN}

Fraktur proksimal femur adalah salah satu patah tulang paling umum terjadi pada populasi lansia dan angka insidennya meningkat seiring dengan peningkatan usia. Fraktur proksimal femur harus ditangani dengan mempertimbangkan usia, status fisik, kualitas tulang dan jenis fraktur. Tujuan utama tatalaksana adalah untuk mencegah kemungkinan komplikasi dengan mengutamakan mobilisasi dini dan membantu pasien kembali ke aktivitas kehidupan sehari-hari mereka Terdapat konsensus yang jelas dalam literatur untuk pengobatan fraktur intertrochanteric stabil, yang biasanya melibatkan metode fiksasi internal. ${ }^{1}$ Namun, modalitas pengobatan yang optimal dari fraktur yang tidak stabil masih tetap kontroversial.

Terdapat berbagai macam intervensi bedah pada fraktur proksimal femur yang tidak stabil. Pada hakekatnya semua intervensi bedah tersebut memiliki tujuan paska operasi yang sama yakni mengembalikan biomekanik dari gaya berjalan dan merehabilitasi pasien ke tingkat fungsi terbaik. Fiksasi internal dengan Cephalomedullary Nailing dan Bipolar Hemiarthroplasty adalah dua pilihan tatalaksana bedah utama untuk fraktur ini. ${ }^{2}$ Fiksasi intramedulla (Cephalomedullary Nailing) dengan menggunakan teknik Proksimal Femoral Nail Antirotation (PFNA) biasanya merupakan metode bedah yang lebih disukai untuk fiksasi internal pada fraktur intertrokanter yang tidak stabil. ${ }^{3}$ Tujuan penggunaan PFN adalah untuk mempertahankan sendi panggul dan untuk menghindari komplikasi yang terkait teknik pembedahan yang lebih invasive seperti Hemiarthroplasti Bipolar. Keuntungan dari PFN adalah durasi operasi yang lebih pendek, teknik bedah minimal invasif, tingkat union yang baik, risiko perdarahan yang lebih rendah dan tingkat morbiditas paska operasi yang lebih rendah. ${ }^{4}$ Meskipun demikian, pasien usia lanjut dengan osteoporosis yang berat dan fraktur intertrokanter yang tidak stabil kadang-kadang membutuhkan waktu imobilisasi yang lebih panjang dan tingkat kegagalan yang lebih tinggi setelah PFN bila dibandingkan dengan Hemiartroplasti Bipolar. Keuntungan dari Hemiartroplasti Bipolar adalah mobilisasi dini dan mencegah komplikasi sistemik karena imobilisasi. Namun, Hemiartroplasti Bipolar juga memiliki beberapa kerugian seperti adanya eksposur bedah yang lebih lebar, potensi kerusakan jaringan yang lebih besar, kehilangan darah yang lebih banyak, risiko dislokasi paska operasi, infeksi, erosi acetabulum dan pelonggaran prostetik.,

Kedua teknik bedah ini memiliki keuntungan dan kerugian masing-masing yang hingga saat ini masih menjadi faktor yang dipertimbangkan oleh dokter ahli bedah ortopedi dalam praktek sehari-hari. Penelitian ini bertujuan untuk mengetahui perbedaan luaran biologis terkait kerusakan jaringan dan luaran fungsional dari teknik Cephalomedullary Nailing dan Hemiartroplasti Bipolar pada penanganan pasien fraktur proksimal femur dengan usia diatas 50 tahun. C-Reactive Protein (CRP) digunakan sebagai penanda inflamasi terkait kerusakan jaringan dan Harris Hip Score sebagai parameter luaran fungsional. Studi ini diharapkan dapat mempermudah pemilihan teknik yang tepat untuk penanganan fraktur proksimal femur.

\section{METODE}

Penelitian dengan rancangan studi kohort prospektif melibatkan pasien fraktur proksimal femur yang menjalani tindakan operasi Hemiarthroplasty Bipolar dan Cephalomedullary Nailing yang direkrut secara konsekutif dari bulan Januari 2019 sampai dengan Februari 2019. Kriteria inklusi sampel diantaranya tindakan operasi Hemiarthroplasti Bipolar atau Proximal Femoral Nail Antirotation (PFNA) dengan metode anestesi spinal dan/ atau epidural, usia lebih dari 50 tahun dan pasien setuju untuk menjadi sampel dalam penelitian ini. Kriteria pengecualian (exclusion) diantaranya pasien dengan riwayat penyakit sistemik, autoimun atau inflamasi, kanker, atau penyakit kronis lainnya dan riwayat konsumsi obat imunosupresif. Adapun kriteria drop out yakni pasien yang mundur menjadi subjek penelitian sebelum tenggang waktu pengukuran selesai, dan pasien meninggal selama perawatan. Pasien yang telah memenuhi kriteria inklusi dan ekslusi diberikan penjelasan mengenai penelitian yang akan dilakukan dan menandatangani lembar persetujuan mengikuti penelitian. Protokol penelitian telah disetujui oleh komite etik Universitas Udayana/RSUP Sanglah Denpasar (No.71/UN.14.2.2.VII.14/LP/2019).

Pasien menjalani prosedur Bipolar Hemiarthroplasty atau Proximal Femoral Nail Antirotation dengan persiapan preoperasi terstandar yang dilakukan oleh bagian Anestesi dan 
pemeriksaan dari bagian Kardiologi dan Penyakit Dalam sesuai indikasi. Pengambilan darah untuk pemeriksaan kadar CRP (random blood sampling) dilakukan sebelum operasi dan 12 jam paska operasi. Pemeriksaan CRP dilakukan di Laboratorium Patologi Klinik RSUP Sanglah. Penilaian aktivitas fungsional pasien menggunakan kuesioner Harris Hip Score dilakukan pada minggu ke-4, minggu ke-6, dan minggu ke 8 paska operasi. Kuisioner terdiri dari pertanyaan mengenai nyeri saat melakukan aktivitas serta kemampuan aktivitas fungsional yang dapat dilakukan oleh pasien. Skor memiliki nilai maksimum 100 poin (kemungkinan fungsi terbaik), meliputi rasa nyeri ( 1 item, $0-44$ poin), fungsi dan aktivitas (7 item, $0-47$ poin), serta rentang gerak dan tidak adanya deformitas (3 item, 0-9 poin). Rentang bagian gerak ( $0-5$ poin) disederhanakan dibandingkan dengan skala aslinya.

Untuk data karakteristik pasien yang masuk ke dalam penelitian dilakukan analisis deskriptif dan ditampilkan dalam tabel. Untuk data numerik dilakukan uji normalitas Shapiro-Wilk dan uji homogenitas varian dengan Levene's Test. Perbedaan rerata antar kelompok dianalisis dengan uji $\mathrm{T}$ independent. Tingkat kemaknaan ( $\alpha$ ) penelitian ini ditetapkan 0,05. Semua analisis statistik dilakukan dengan menggunakan program perangkat lunak SPSS for Windows (Versi 22; IBM Corp, NY, USA).

\section{HASIL}

Total 42 sampel yang menjalani prosedur Hemiarthroplasti Bipolar dan PFNA ikut serta dalam penelitian ini. Jumlah sampel yang menjalani prosedur berjumlah sama, yakni masing-masing 21 orang. Fraktur kolum femur merupakan kasus yang paling banyak menjalani prosedur Hemiarthroplasti
Bipolar, dan fraktur intertrokanter femur paling banyak menjalani prosedur PFNA. Rerata usia pada sampel adalah $70,6 \pm 11,1$ tahun. Rerata usia pasien yang menjalani Hemiarthroplasti Bipolar dan PFNA adalah $68,7 \pm 9,9$ dan $72,6 \pm 11,9$ tahun, secara berturut-turut. Gambaran umum sampel penelitian disajikan pada tabel 1 .

Secara umum kadar CRP preoperasi pada kedua kelompok tidak berbeda signifikan $(p>0,05)$, sedangkan pada paska operasi serta kadar CRP Hemiarthroplasti Bipolar secara signifikan lebih tinggi daripada PFNA $(p<0,0001)$. Hasil yang sama juga ditunjukan dari analisis selisih CRP paska operasi dan preoperasi $(\triangle \mathrm{CRP})$ menunjukan hasil yang secara statistic berbeda signifikan $(p<0,0001)$.

Pada penilaian HHS, skor paling tinggi ditunjukan pada pemeriksaan di minggu ke-8 baik pada kelompok Hemiarthroplasti Bipolar maupun kelompok PFNA. Secara umum rerata skor HHS lebih tinggi pada kelompok Hemiarthroplasti Bipolar daripada PFNA pada setiap kali pengukuran (tabel 3). Data HHS pada kelompok PFNA maupun Hemiarthroplasti Bipolar pada minggu ke-4, ke-6, dan ke- 8 berdistribusi normal $(p>0,05)$ serta memiliki varian yang homogen $(p>0,05)$. Uji General Linear Model dengan Pillai's Trace, Wilks Lambda, Hotelling's Trace, Roy's largest root mendapatkan nilai $p<0,0001$, yang menunjukan bahwa terdapat perbedaan yang bermakna antara HHS paska operasi minggu ke-4, ke-6, dan ke-8 antara prosedur Hemiarthroplasti Bipolar dan PFNA.

Penelitian ini juga menganalisis perbedaan lama waktu rawat inap paska operasi (length of stay) dan jumlah perdarahan pada kedua kelompok pembedahan. Tampak pada tabel 4, lama waktu rawat inap paska operasi pada kelompok Hemiarthroplasti Bipolar 56\% lebih lama dibandingkan kelompok

Tabel 1 Distribusi Karakteristik Subjek Penelitian

\begin{tabular}{|c|c|c|c|c|}
\hline & Kelompok & Karakteristik & Frekuensi & Persentase \\
\hline \multirow[t]{4}{*}{ Jenis Kelamin } & Bipolar & Laki-laki & 8 & $38.1 \%$ \\
\hline & Hemiarthroplasti & Perempuan & 13 & $61.9 \%$ \\
\hline & PFNA & Laki-laki & 10 & $47.6 \%$ \\
\hline & & Perempuan & 11 & $52.4 \%$ \\
\hline \multirow{4}{*}{$\begin{array}{l}\text { Sisi Ekstremitas } \\
\text { Inferior }\end{array}$} & Bipolar & Kanan & 11 & $52.4 \%$ \\
\hline & Hemiarthroplasti & Kiri & 10 & $47.6 \%$ \\
\hline & PFNA & Kanan & 10 & $47.6 \%$ \\
\hline & & Kiri & 11 & $52.4 \%$ \\
\hline \multirow[t]{4}{*}{ Diagnosis } & Hemiarthroplasti & Fraktur Intertrochanter Femur & 9 & $38.1 \%$ \\
\hline & Bipolar & Fraktur Collum Femur & 12 & $57.1 \%$ \\
\hline & PFNA & Fraktur Intertrochanter Femur & 18 & $85,7 \%$ \\
\hline & & Fraktur Collum Femur & 3 & $14,3 \%$ \\
\hline
\end{tabular}


Tabel 2 Kadar CRP pada masing-masing kelompok

\begin{tabular}{llcc}
\hline Variabel & Kelompok & Mean (SD) dalam $\mathbf{~ g / L ~}$ & Shapiro-Wilk (Nilai $\boldsymbol{p}$ ) \\
\hline \multirow{2}{*}{ Preoperasi } & Hemiarthroplasti Bipolar & $32,4(16,7)$ & 0,151 \\
& PFNA & $33,7(17,1)$ & 0,260 \\
\multirow{2}{*}{ Paska operasi } & Hemiarthroplasti Bipolar & $76,5(27,3)$ & 0,702 \\
& PFNA & $42,6(17,6)$ & 0,706 \\
\multirow{2}{*}{ Delta CRP } & Hemiarthroplasti Bipolar & $45,1(22,1)$ & 0,136 \\
& PFNA & $8,9(3,2)$ & 0,645 \\
\hline
\end{tabular}

Tabel 3 Rerata Harris Hip Score pada masing-masing kelompok

\begin{tabular}{llcc}
\hline & Kelompok & Rerata (SD) & Shapiro-Wilk (Nilai p) \\
\hline Minggu 4 & Hemiarthroplasti Bipolar PFNA & $52,3(4,2)$ & 0,465 \\
& & $52,2(5,4)$ & 0,167 \\
Minggu 6 & Hemiarthroplasti Bipolar PFNA & $76,5(4,6)$ & 0,373 \\
& & $61,4(5,4)$ & 0,907 \\
Minggu 8 & Hemiarthroplasti Bipolar PFNA & $89.4(4,5)$ & 0,099 \\
& & $74.9(4,9)$ & 0,986
\end{tabular}

Tabel 4 Lama Rawat dan Jumlah Perdarahan

\begin{tabular}{llccc}
\hline & Kelompok & Rerata & Standar Deviasi & Shapiro-Wilk (Nilai $\boldsymbol{p}$ ) \\
\hline Lama waktu perawatan & Hemiarthroplasti Bipolar & 6,1 & 1,3 & 0,063 \\
(hari) & PFNA & 3,9 & 1,3 & 0,089 \\
Jumlah Perdarahan (ml) & Hemiarthroplasti Bipolar & 407,4 & 122,8 & 0,248 \\
& PFNA & 90 & 13 & 0,080 \\
\hline
\end{tabular}

paska operasi PFNA. Lama waktu rawat inap (length of stay) pada kelompok Hemiarthroplasti Bipolar dan PFNA berdistribusi normal $(p>0,05)$ serta uji Levene's test menunjukkan varian homogen $(p>0,05)$. Uji-T independen menunjukan bahwa perbedaan lama rawat inap paska operasi tersebut bermakna secara statistik $(p<0,0001)$. Terkait rerata volume perdarahan, teknik Hemiarthroplasti Bipolar memiliki volume perdarahan 4,5 kali lebih banyak. Jumlah perdarahan pada kelompok Hemiarthroplasti Bipolar dan PFNA berdistribusi normal $(p>0,05)$ serta uji Levene's test menunjukkan varian homogen $(p>0,05)$. Uji-T independen mengkonfirmasi bahwa terdapat perbedaan yang bermakna terkait jumlah perdarahan antara kelompok Hemiarthroplasti Bipolar dan PFNA $(p<0,0001)$.

\section{PEMBAHASAN}

Prosedur operasi Hemiarthroplasti Bipolar dan PFNA merupakan pilihan utama penatalaksanaan fraktur proksimal femur yang berdasarkan penelitian terdahulu menunjukan keunggulan masing-masing pada latar belakang dan kondisi yang berbeda-beda. Adapun pertimbangan yang sering dijadikan acuan yaitu umur dan konfigurasi fraktur. Penelitian ini bertujuan untuk melihat luaran fungsional dan biologis kedua teknik yang dinilai dari Harris Hip Score dan selisih CRP sebelum dan paska operasi. Pasien dipantau selama 8 minggu setelah operasi untuk dilihat perkembangannya yang dinilai dengan HHS pada minggu ke 4, 6, dan 8. Selain itu penilaian juga didasarkan pada selisih kadar CRP sebelum dan seletah operasi sebagai indikator biologis.

Pada penelitian ini $\triangle \mathrm{CRP}$ digunakan sebagai parameter tingkat inflamasi akibat kerusakan jaringan dari kedua prosedur. CRP sebagian besar disekresikan oleh hati dan dimulai empat hingga enam jam setelah stimulus. Kadar CRP belipat ganda setiap delapan jam, dan memuncak dalam 36 hingga 50 jam. Konsentrasi plasma CRP meningkat selama keadaan inflamasi, karakteristik yang telah lama digunakan untuk tujuan klinis. ${ }^{78}$ Hasil penelitian ini menujukan bahwa prosedur Hemiarthroplasti Bipolar menghasilkan trauma dan inflamasi yang lebih besar bila dibandingkan dengan PFNA sesuai dengan $\triangle$ CRP 5 kali lebih besar. Hemiarthropolasti Bipolar merupakan 
tindakan invasif yang bertujuan untuk mengganti bagian sendi panggul yang dalam prosesnya akan menimbulkan peradangan dan risiko komplikasi paska operasi. ${ }^{9}$

Hasil penilaian fungsional dengan skor HHS menunjukan Hemiarthroplasti Bipolar memiliki luaran fungsional yang lebih baik dari PFNA pada tiap periode penilaian. Pada minggu ke-4 nilai rerata HHS tidak menunjukan perbedaan yang signifikan antara kedua prosedur $(52,3 \pm 4,2$ vs $52,2 \pm 5,4)$. Selain itu, secara kategori skor tersebut masih tergolong buruk. Evaluasi berikutnya pada minggu ke-6 menunjukan keunggulan dari Hemiarthroplasti Bipolar dengan rerata HHS $76,5 \pm 4,6$ sementara PFNA $61,4 \pm 5,4 \quad(p<0,0001)$. Secara kategori, Hemiarthroplasti Bipolar masuk dalam katagori sedang sedangkan PFNA masih dalam katagori buruk. Pada minggu ke-8, HHS pada Hemiarthroplasti Bipolar tergolong baik $(89,43 \pm 4,5)$ dan PFNA tergolong sedang $(74,95 \pm 4,9)$. Keduanya berbeda signifikan secara statistik $(p<0,0001)$.

Penilaian HHS dilakukan pada minggu ke 4, 6 dan 8 paska operasi pada pasien dengan Hemiarthroplasti Bipolar dan PFNA dengan tujuan untuk menyediakan informasi yang dibutuhkan dalam menilai kondisi awal paska operasi dan perkembangan di minggu-minggu berikutnya. Hal ini dirasa perlu mengingat Hemiarthroplasti Bipolar merupakan tindakan yang lebih invasif bila dibandingkan dengan PFNA. Studi oleh Min dkk, menyebutkan bahwa Hemiarthroplasti Bipolar merupakan tindakan bedah dengan perlukaan dan risiko komplikasi yang lebih besar bila dibandingkan dengan PFNA. ${ }^{5}$ Dari hasil tersebut dapat dikatakan pada periode awal paska operasi tidak terdapat perbedaan yang signifikan terkiat luaran hasil operasi hingga minggu ke 6 dan 8 . Hal tersebut dapat disebabkan oleh faktor penyembuhan luka operasi yang berhubungan dengan aktivitas, range of motion, dan tingkat nyeri pada pasien. Hal ini menarik untuk dikaji mengingat sumber lain menyatakan bahwa hasil akhir dari tindakan Hemiarthroplasti Bipolar memiliki luaran fungsional yang lebih buruk bila dibandingkan dengan PFNA. Hal ini sesuai dengan studi oleh Kumar dkk. pada tahun 2019 yang meneliti luaran fungsional 6 bulan paska operasi. ${ }^{10}$

Rerata lama rawat inap paska operasi pada kelompok Hemiarthroplasti Bipolar yaitu $6,1 \pm 1,4$ hari dan untuk kelompok PFNA sebesar $3,9 \pm 1,3$ hari. Keduanya berbeda signifikan secara statistik $(\mathrm{P}<0,0001)$. Beberapa faktor yang dirasa berperan dalam durasi rawat inap pada pasien yang menjalani prosedur operasi antara lain usia, jenis operasi, jumlah perdarahan, dan perkembangan komplikasi paska operasi. ${ }^{11}$ Hemiarthroplasti
Bipolar yang merupakan tindakan lebih invasif yang dapat dilihat dari delta CRP dan lama rawat inap paska operasi yang lebih panjang. ${ }^{12} \mathrm{Hal}$ ini perlu menjadi bahan pertimbangan dalam pemilihan pasien yang akan menjalani prosedur ini mengingat kemungkinan biaya yang lebih tinggi dan tingkat risiko komplikasi yang semakin besar seiring kemungkinan lama rawat paska operasi di rumah sakit yang lebih lama. Lagoe dkk., pada tahun 2011 menyimpulkan bahwa lama perawatan di rumah sakit berhubungan dengan kejadian infeksi nosokimial terutama pada sistem respirasi dan ulkus dekubitus akibat imobilisasi. ${ }^{13}$

Perdarahan merupakan komplikasi utama pada setiap prosedur operasi yang berpotensi meningkatan angka mortalitas terutama pada usia lanjut. Terdapat perbedaan yang signifikan antara jumlah perdarahan kedua teknik bedah tersebut. Sesuai dengan dasar teori dan studi oleh Esen dkk., PFNA merupakan prosedur yang memiliki kelebihan yakni minimal invasif, durasi operasi yang lebih pendek, dan risiko komplikasi yang lebih rendah bila dibandingkan dengan Hemiarthroplasti Bipolar. ${ }^{14}$ Transfusi packed red blood cell paska operasi masih menjadi modalitas dalam menurunkan angka komplikasi akibat perdarahan paska operasi. Hal tersebut akan berdampak pada penambah beban biaya dan transfusi juga memiliki risiko komplikasi tersendiri. Sudah sebaiknya hal tersebut menjadi bahan pertimbangan dalam pemilihan pasien sebagai kandidat untuk menjalani Hemiarthroplasti Bipolar, terlebih sebagian besar pasien dengan fraktur panggul berusia tua.

\section{SIMPULAN}

Peningkatan kadar CRP pada 12 jam paska operasi Hemiartroplasti Bipolar lebih tinggi secata signifikan dibandingkan dengan Cephalomedullary Nailing. Skor fungsional Harris Hip Score pada kelompok yang menjalani operasi Hemiartroplasti Bipolar secara signifikan lebih tinggi dibandingkan kelompok yang menjalani operasi Cephalomedullary Nailing dimulai setelah 6 minggu paska operasi.

\section{KONFLIK KEPENTINGAN}

Tidak ada.

\section{ETIKA PENELITIAN}

Penelitian ini telah mendapat persetujuan etik oleh Komisi Etik, Fakultas Kedokteran Universitas Udayana/RSUP Sanglah Denpasar, Bali, Indonesia sebelum penelitian berjalan (No.71/ UN.14.2.2.VII.14/LP/2019). 


\section{PENDANAAN}

Penulis bertanggung jawab terhadap pendanaan penelitian ini tanpa melibatkan pihak sponsor, beasiswa, ataupun sumber pendanaan lainnya.

\section{KONTRIBUSI PENULIS}

Seluruh penulis berkontribusi terhadap penelitian ini baik dari perencaan proposal penelitian, pencarian data, analisis data penelitian, hingga interpretasi dan penyusunan naskah publikasi.

\section{DAFTAR PUSTAKA}

1. Saudan M., Lübbeke A., Sadowski C., Riand N., Stern R., Hoffmeyer P. Pertrochanteric Fractures: Is There an Advantage to an Intramedullary Nail? J Orthop Trauma. 2002;16(6):386-93.

2. Bakker A., Blokhuis T., Meeks M., Hermens H., Holtslag H. Dynamic weight loading in older people with hip fracture. J Rehabil Med. 2014;46(7):708-11.

3. Tang P., Hu F., Shen J., Zhang L., Zhang L. Proximal femoral nail antirotation versus hemiarthroplasty: A study for the treatment of intertrochanteric fractures. Injury. 2012;43(6):876-81.

4. Parker M.J., Handoll H.H.G. Intramedullary nails for extracapsular hip fractures in adults. In: Cochrane Database of Systematic Reviews. John Wiley \& Sons, Ltd; 2006.

5. Min W.-K., Kim S.-Y., Kim T.-K., Lee K.-B., Cho M.-R., Ha Y.-C., et al. Proximal Femoral Nail for the Treatment of Reverse Obliquity Intertrochanteric Fractures Compared With Gamma Nail. J Trauma Inj Infect Crit Care. 2007;63(5):1054-60.

6. Kakkar R., Kumar S., Singh A.K. Cephalomedullary nailing for proximal femoral fractures. Int Orthop. 2005/01/13. 2005;29(1):21-4.
7. Young B., Gleeson M., Cripps A.W. C-reactive protein: A critical review. Pathology. 1991;23(2):118-24.

8. Wiryadana K.A., Supadmanaba I.G.P., Samatra D.P.G.P. Progress and potential roles blood biomarkers of ischemic stroke in clinical setting. Indones J Biomed Sci. 2017;11(2):19-29.

9. Bonnevialle P., Saragaglia D., Ehlinger M., Tonetti J., Maisse N., Adam P., et al. Trochanteric locking nail versus arthroplasty in unstable intertrochanteric fracture in patients aged over 75 years. Orthop Traumatol Surg Res. 2011;97(6):S95-100.

10. Kumar P., Rajnish R.K., Sharma S., Dhillon M.S. Proximal femoral nailing is superior to hemiarthroplasty in $\mathrm{AO} /$ OTA A2 and A3 intertrochanteric femur fractures in the elderly: a systematic literature review and meta-analysis. Int Orthop. 2020;44(4):623-33.

11. Lee S.Y., Lee S.-H., Tan J.H.H., Foo H.S.L., Phan P.H, Kow A.W.C., et al. Factors associated with prolonged length of stay for elective hepatobiliary and neurosurgery patients: a retrospective medical record review. $B M C$ Health Serv Res. 2018;18(1):5.

12. Munot S., Saraf H. Comparative study of PFN antirotation vs bipolar hemiarthroplasty in unstable senile intertrochanteric fractures. Indian J Orthop Surg. 2018;4(4):380-5.

13. Lagoe R.J., Johnson P.E., Murphy M.P. Inpatient hospital complications and lengths of stay: a short report. BMC Res Notes. 2011;4:135.

14. Esen E. Evaluation of proximal femoral nail-antirotation and cemented, bipolar hemiarthroplasty with calcar replacement in treatment of intertrochanteric femoral fractures in terms of mortality and morbidity ratios. Jt Dis Relat Surg. 2017;28(1):35-40.

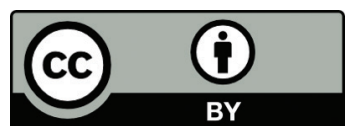

This work is licensed under a Creative Commons Attribution 